Article

\title{
Rare Earth Element Distributions in Continental Shelf Sediment, Northern South China Sea
}

\author{
Qian Ge 1,2,* Z. George Xue ${ }^{3,4,5}$ and Fengyou Chu 1,2 \\ 1 Key Laboratory of Submarine Geosciences, Ministry of Natural Resources, Hangzhou 310012, China; \\ chu@sio.org.cn \\ 2 Second Institute of Oceanography, Ministry of Natural Resources, Hangzhou 310012, China \\ 3 Department of Oceanography and Coastal Sciences, Louisiana State University, Baton Rouge, LA 70803, USA; \\ zxue@lsu.edu \\ 4 Center for Computation and Technology, Louisiana State University, Baton Rouge, LA 70803, USA \\ 5 Coastal Studies Institute, Louisiana State University, Baton Rouge, LA 70803, USA \\ * Correspondence: qge@sio.org.cn
}

Received: 16 October 2020; Accepted: 11 December 2020; Published: 16 December 2020

\begin{abstract}
A total of 388 surface sediment samples taken from the northern South China Sea (SCS) continental shelf were analyzed to characterize the signature of their rare earth elements (REEs). The average REEs concentration was $192.94 \mu \mathrm{g} / \mathrm{g}$, with a maximum of $349.07 \mu \mathrm{g} / \mathrm{g}$, and a minimum of $32.97 \mu \mathrm{g} / \mathrm{g}$. The chondrite-normalized REEs pattern exhibits a remarkably light REEs accumulation, a relatively flat heavy REEs pattern, and a negative Eu anomaly. We subdivided the study area into three zones using the characteristics of REEs and statistical characteristics. Zone I: continental shelf off western Guangdong Province. Here, the sediment provenance is mainly river-derived from the Pearl River, Taiwanese rivers, and those in the adjacent area. Zone II: Qiongzhou Strait and Leizhou Peninsula. Here, the sediment provenance consists of the Qiongzhou Strait and the Hainan Island. Zone III: Hainan Island and SCS slope sediments are dominated. The REEs compositions are mainly controlled by source rock properties, hydrodynamic conditions, and an intensity of chemical weathering. We reconstructed the sediment dispersal and transport route using the REEs compositions, grain size, and other geochemical characteristics throughout the study area.
\end{abstract}

Keywords: rare earth elements; Pearl River; provenance; transportation and depositional processes

\section{Introduction}

The source of sediment is one of the key topics in modern marine sedimentary geology [1]. It is important to establish the provenance of sediment to understand the geological and paleoclimatic history presented therein. Terrigenous materials retain the information of the source rock properties, the sedimentation affects, and changes in the composition of the sediments. The unique stability of rare earth elements (REEs) makes them strong inheritance to the parent rock, and thus, they could be used to indicate the evolution of sediment provenance [2]. Once the REEs enter the marine environment, the REEs compositions and distribution patterns for the sediments basically do not change significantly [3]. Therefore, the study of the REEs in marine sediments can provide help for provenance determination, environmental evolution, and stratigraphic correlation [4-8].

Previous studies systematically analyzed the characteristics of REEs in seafloor sediments of the Northwestern Pacific (Bohai Sea, Yellow Sea, and East China Sea [6,9-11]). The South China Sea (SCS) contains significant information about the materials and energy exchange between the Pacific Ocean and the marginal sea in Chinese coastal waters. In recent years, a breakthrough has been made in understanding the evolution of the paleoclimate and the history of the East Asian monsoon 
in this region [12-15]. As the area with strong weathering and erosion, the origination, transport, and deposition of the SCS sediments are highly localized and complicated. Comprehensive concepts of the transport and accumulation processes of the weathering and erosion products still remain poorly understood [16]. The northern SCS, which is adjacent to the Chinese mainland and Taiwan, receives significant amounts of terrigenous materials [17]. The northern SCS sediments are good proxies for analyzing the sedimentary processes from source to sink. This study selects 388 surface sediment samples (Figure 1) for REEs analysis to (1) delineate the REEs distribution and concentrations in surface sediments of the northern SCS continental shelf; (2) evaluate controlling factors of the REEs distribution patterns; and (3) investigate modern sediment provenance and their transportation processes.

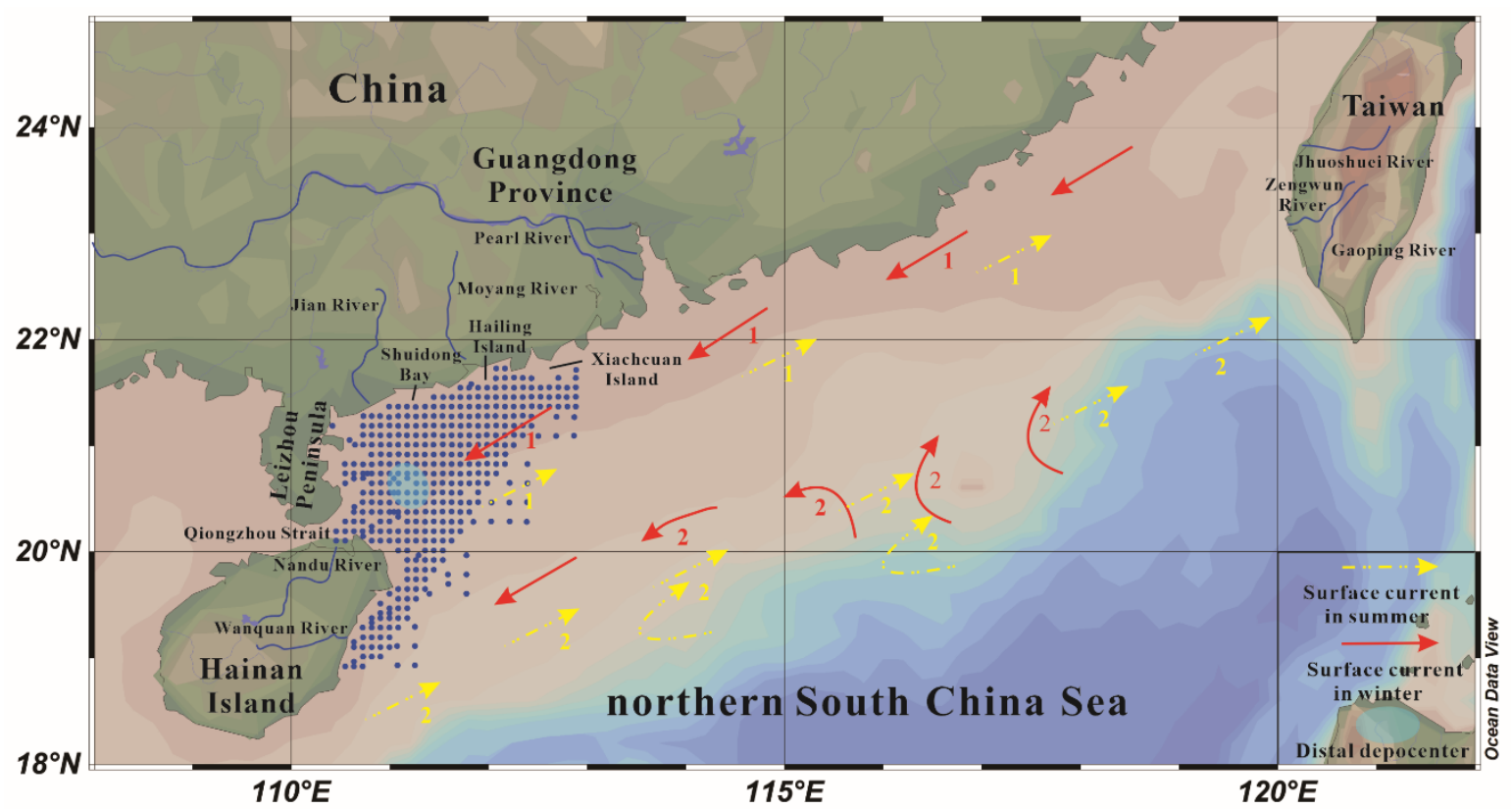

Figure 1. Location of surface sediment samples on the northern South China Sea continental shelf. The location of distal depocenter is cited from Ge et al. [17]. Seasonal variations of surface circulation patterns on the northern South China Sea continental shelf are revised from Liu et al. [16]. 1. Chinese Coastal Current; 2. South China Sea Warm Current.

\section{Materials and Methods}

During a joint cruise between the Second Institute of Oceanography, Ministry of Natural Resources, and South China Sea Bureau of Ministry of Natural Resources in 2008, we collected 388 surface sediment samples using a box corer at water depth around 4-135 m (for the samples locations, see Figure 1). The samples were stored at $4{ }^{\circ} \mathrm{C}$ immediately after collection. The grain size was measured using a Mastersizer-2000 laser particle size analyzer in Nanjing University and South China Sea Bureau of Ministry of Natural Resources. The procedure of grain size analysis is reported in Ge et al. [18]. The identification of REEs constituents, La, Ce, Pr, Nd, Sm, Eu, Gd, Tb, Dy, Ho, Er, Tm, Yb, Lu, and Y were carried out at the Institute of Geophysical and Geochemical Exploration, Chinese Academy of Geological Sciences, China, using an Inductively Coupled Plasma Mass Spectrometer (ICP-MS) (iCAP Qc, Thermo Fisher Scientific, Waltham, MA, USA). The sample was dried at $105^{\circ} \mathrm{C}$ for $12 \mathrm{~h}$ and was crushed by agate mortar ( $200 \mathrm{mesh}, \approx 0.074 \mathrm{~mm}$ pore size). Then, the powdered samples $(0.05 \mathrm{~g})$ were digested using high-purity $\mathrm{HNO}_{3}(1.5 \mathrm{~mL}$ ) and $\mathrm{HF}$ (hydrofluoric acid, $1.5 \mathrm{~mL}$ ) in a tightly closed Teflon bomb for $48 \mathrm{~h}$ at $190{ }^{\circ} \mathrm{C}$. To remove residual $\mathrm{HF}$, the dry samples were retreated with $\mathrm{HNO}_{3}$ $(1 \mathrm{~mL})$. Then, the samples were digested with $50 \% \mathrm{HNO}_{3}(3 \mathrm{~mL})$ in a tightly closed Teflon bomb for another $12 \mathrm{~h}\left(190^{\circ} \mathrm{C}\right)$. After cooling, the final solution was transferred to a $100 \mathrm{~mL}$ polyethylene bottle, to which we added $1 \mathrm{~mL}(\mathrm{Rh}+\mathrm{Re})$ of mixed standard solution and then diluted it by the addition 
of Milli-Q water for analysis. The GSD-9 and GSD-10 sediment samples were analyzed for quality assurance and control, which showed a less than $5 \%$ REEs error.

\section{Results}

\subsection{Grain Size Parameters}

The results of grain size are reported in Ge et al. [18], and they show that the average values of sand, silt, and clay fractions are $25 \%, 62 \%$, and $13 \%$, respectively. The contents of clay and silt fractions exhibit a similar pattern, having high values on the shelf off western Guangdong Province, which are opposite to those of sand fractions. The mean grain size (Mz) ranges from $0.05 \varphi$ to $7.28 \varphi$, with a mean value of $5.60 \varphi$.

\subsection{Concentrations and Spatial Characteristics of REEs}

Table 1 shows the total concentrations of REEs ( $\sum$ REE). The mean $\sum$ REE of surface sediments is $192.94 \mu \mathrm{g} / \mathrm{g}$, with a minimum and maximum value of 32.97 and $349.07 \mu \mathrm{g} / \mathrm{g}$, respectively. The light REEs (LREE, from La to Eu) exhibit a mean value of $154.36 \mu \mathrm{g} / \mathrm{g}$, dominating the REEs content; the mean value of heavy REEs (HREE, from Gd to $\mathrm{Lu}$ ) is $16.11 \mu \mathrm{g} / \mathrm{g}$. The LREE/HREE values range from 5.91 to 10.93 with an averaged value of 9.50. The $\sum$ REE exhibit significant spatial variabilities in the study area (Figure 2). The high $\sum$ REE values are found in the western Guangdong coastal waters. Two accumulation centers are identified around the Xiachuan and Hailing Islands (Figures 1 and 2), where the $\sum R E E$ values can reach more than $250 \mu \mathrm{g} / \mathrm{g}$. Another high $\sum R E E$ value area was found and correlated to a distal depocenter (Figures 1 and 2), which is mentioned in Ge et al. [17]. The values decrease as waters are moving off the Guangdong coast. The lowest value is located in the continental shelf off the eastern Leizhou Peninsula and Qiongzhou Strait, where the $\sum$ REE values are mostly lower than $100 \mu \mathrm{g} / \mathrm{g}$. The LREE and HREE exhibit similar spatial characteristics with $\sum R E E$, yet with a slightly smaller spatial gradient (Figure 2).

\subsection{The REEs Fractionation Characteristics}

To further investigate the fractionation characteristics of REEs, the chondrite-normalized REEs of sediments were analyzed [19]. The trends reflect a remarkable accumulation of LREE. The even distribution of HREE is relatively flat (Figure 3), with the $(\mathrm{La} / \mathrm{Yb})_{\mathrm{N}}$ ranging from 5.87 to 15.21 (Table 1). The fractionation level of REEs was determined following, where cerium and europium anomalies ( $\delta \mathrm{Ce}$ and $\delta \mathrm{Eu}$ ) are derived by the comparison between the concentrations of $\mathrm{Ce}$ and $\mathrm{Eu}$ and those of their neighboring elements [20]:

$$
\begin{aligned}
\delta \mathrm{Ce} & =\mathrm{Ce}_{\mathrm{N}} /\left(\mathrm{La}_{\mathrm{N}} \times \mathrm{Pr}_{\mathrm{N}}\right)^{1 / 2} \\
\delta \mathrm{Eu} & =\mathrm{Eu}_{\mathrm{N}} /\left(\mathrm{Sm}_{\mathrm{N}} \times \mathrm{Gd}_{\mathrm{N}}\right)^{1 / 2}
\end{aligned}
$$

where $\mathrm{N}$ is the normalization to chondrite [19]. The $\delta$ Ce ranges from 0.79 to 1.08 with a mean value of 0.97 . No notable Ce anomaly was identified. The $\delta$ Eu ranges from 0.28 to 1.05 with a mean value of 0.65 (Table 1), exhibiting a negative anomaly. 
Table 1. Statistical data of rare earth elements (REEs) values ( $\mu \mathrm{g} / \mathrm{g})$ in surface sediments taken from the northern South China Sea continental shelf, together with some important fractionation parameters.

\begin{tabular}{|c|c|c|c|c|c|c|c|c|c|c|c|c|c|c|c|c|c|c|c|c|c|}
\hline Statistics & La & $\mathrm{Ce}$ & $\operatorname{Pr}$ & $\mathrm{Nd}$ & $\mathrm{Sm}$ & Eu & Gd & $\mathrm{Tb}$ & Dy & Ho & Er & $\mathrm{Tm}$ & $\mathrm{Yb}$ & $\mathbf{L u}$ & $\mathrm{Y}$ & $\sum$ REE & LREE & HREE & $\delta \mathrm{Eu}$ & $\delta \mathrm{Ce}$ & $(\mathrm{La} / \mathrm{Yb})_{\mathrm{N}}$ \\
\hline Min & 6.80 & 10.00 & 1.40 & 4.70 & 0.97 & 0.21 & 0.95 & 0.16 & 0.91 & 0.18 & 0.51 & 0.08 & 0.51 & 0.07 & 5.40 & 32.97 & 24.20 & 3.41 & 0.28 & 0.79 & 5.87 \\
\hline $\operatorname{Max}$ & 73.40 & 125.40 & 14.90 & 49.40 & 9.39 & 1.83 & 8.79 & 1.42 & 8.37 & 1.68 & 5.15 & 0.77 & 4.58 & 0.71 & 44.30 & 349.07 & 273.30 & 31.47 & 1.05 & 1.08 & 15.21 \\
\hline Average & 38.50 & 71.50 & 8.32 & 29.30 & 5.64 & 1.11 & 4.85 & 0.78 & 4.31 & 0.83 & 2.32 & 0.38 & 2.28 & 0.37 & 22.46 & 192.94 & 154.36 & 16.11 & 0.65 & 0.97 & 12.12 \\
\hline Standard deviation & 12.40 & 23.60 & 2.68 & 9.50 & 1.84 & 0.37 & 1.56 & 0.26 & 1.40 & 0.27 & 0.76 & 0.13 & 0.75 & 0.13 & 7.21 & 62.14 & 50.03 & 5.22 & 0.06 & 0.06 & 1.36 \\
\hline
\end{tabular}
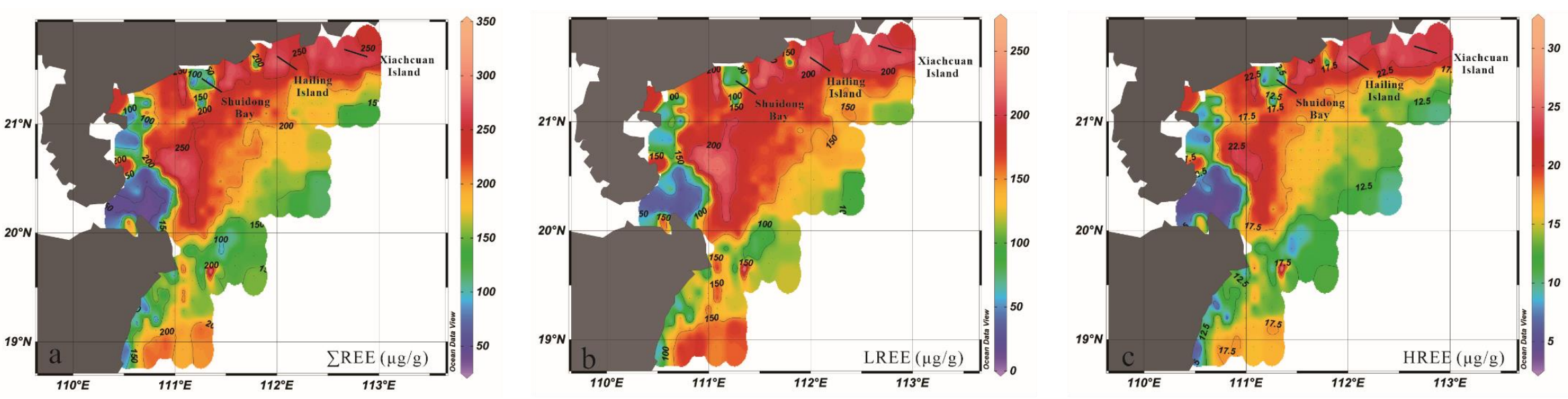

Figure 2. Spatial characteristics of REEs in the surface sediments of the northern South China Sea continental shelf ((a) $\sum$ REE; (b) LREE; (c) HREE). 


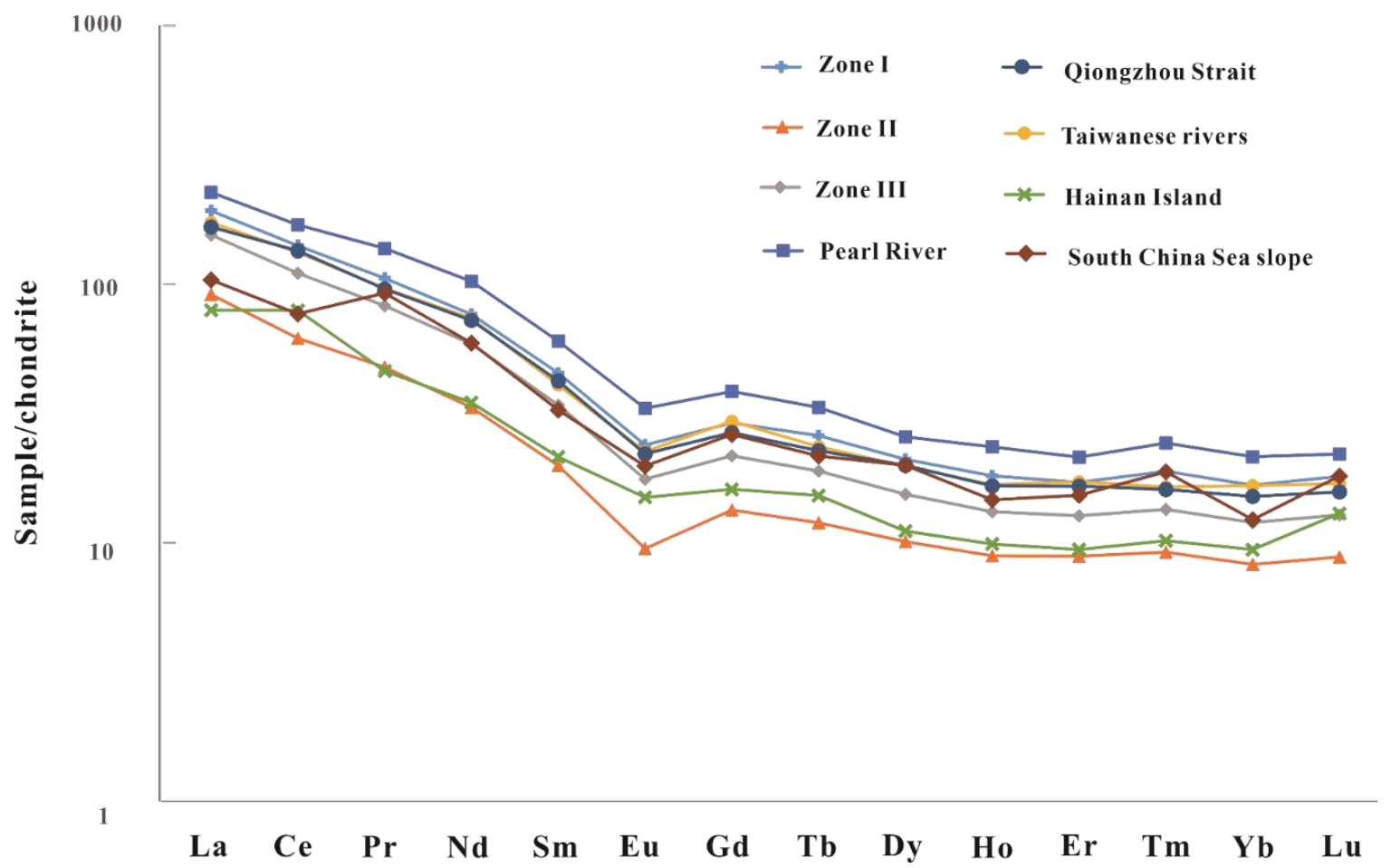

Figure 3. Chondrite-normalized REEs distribution patterns of the samples in the study area (three different zones) and the samples from the Pearl River [21], Qiongzhou Strait [22], Taiwanese rivers [23], Hainan Island [24], and South China Sea slope [25].

\subsection{Spatial Zones of REEs}

The Q-cluster analysis has been widely used for the sediment distribution analyses $[18,26,27]$. We performed the Q-cluster analysis to investigate the spatial relationships among all REEs. These analyses are carried out on the original data using Statistical Product and Service Solutions software. The Q-cluster analysis indicated that the study area can be grouped into three zones (Figure 4), which is similar to our previous study based on major elements [18]. Zone I designates the continental shelf off the western Guangdong Province and distal depocenter extending to the southwest. The mean $\sum$ REE value of sediments in this zone is $233.96 \mu \mathrm{g} / \mathrm{g}$. Zone II comprises the coastal area off Leizhou Peninsula and the eastern exit of Qiongzhou Strait. The average value of $\sum$ REE is $107.00 \mu \mathrm{g} / \mathrm{g}$. Zone III is located on the outer shelf (water depth $>50 \mathrm{~m}$ ) to the east of Hainan Island. The mean $\sum$ REE value of sediments in this zone is $180.81 \mu \mathrm{g} / \mathrm{g}$ (Table 2). In addition, the chondrite-normalized REEs parameters in different zones, such as $\delta \mathrm{Ce}, \delta \mathrm{Eu},(\mathrm{La} / \mathrm{Sm})_{\mathrm{N}}$, and $(\mathrm{Gd} / \mathrm{Lu})_{\mathrm{N}}$, are shown in Table 2.

Table 2. REEs characteristic parameters and mean contents of heavy minerals in three zones.

\begin{tabular}{|c|c|c|c|c|c|c|c|}
\hline Zones & $\delta \mathrm{Ce}$ & $\delta \mathrm{Eu}$ & $\sum \operatorname{REE}(\mu \mathrm{g} / \mathrm{g})$ & LREE/HREE & $(\mathrm{La} / \mathrm{Sm})_{\mathrm{N}}$ & $(\mathrm{Gd} / \mathrm{Lu})_{\mathrm{N}}$ & Contents of Heavy Minerals a $(\%)$ \\
\hline I & 0.99 & 0.66 & 223.96 & 9.32 & 4.24 & 1.74 & 0.95 \\
\hline II & 0.92 & 0.63 & 107.00 & 8.20 & 4.46 & 1.62 & 2.76 \\
\hline III & 0.97 & 0.65 & 180.81 & 9.94 & 4.59 & 1.81 & 0.89 \\
\hline
\end{tabular}




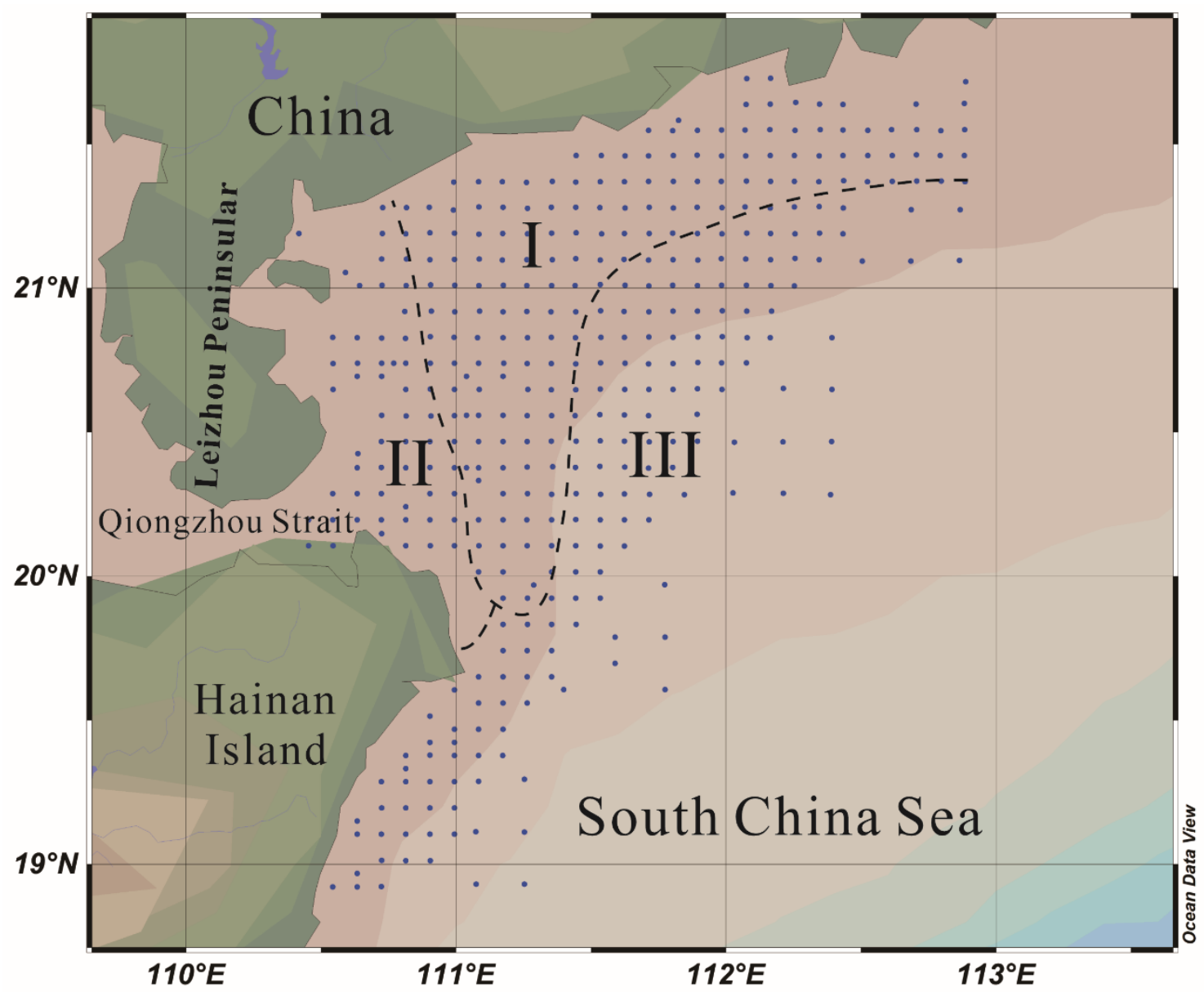

Figure 4. Three REEs geochemical zones on the northern South China Sea continental shelf (dashed lines represent the estimated boundary of REEs zones).

\section{Discussion}

\subsection{Controlling Factors of REEs Compositions}

Many factors are responsible for REEs compositions in sediments, including source rock properties, intensity of chemical weathering, mineralogy, grain size, and diagenesis [6,29]. Among these factors, source rock properties (sediment provenance) are regarded as the most important controlling factor $[2,6]$, which will be discussed in the next section.

We found strong correlations between $\sum$ REE and granulometric data (contents of sand, silt, and clay, Mz, Figure 5) [18]. In general, low $\sum$ REE values are found in coarse-grained sediments, while high $\sum R E E$ values are found in fine-grained sediments. There is a strong correlation between the $\sum$ REE of the fine-grained fraction and coarse-grained fraction. Such a correlation is consistent with the "element granularity control rate" mechanism, which indicates that $\sum R E E$ values are rich in the fine fractions and deficit in the coarse sediments [30]. Hydrodynamics controls the transportation, re-suspension, and deposition of sediments, and thus, they can explain the spatial characteristics of $\sum$ REE and the dominant effect of grain size on the $\sum$ REE [27]. The surface sediments are mainly transported from the surrounding rivers. The riverine sediments are deposited on the continental shelf around the estuaries in summer. In the following winter, the coastal current transports the re-suspended sediments southwestwardly $[17,18]$. The $\sum$ REE values in this region are high. The low $\sum$ REE values in Shuidong Bay (Figures 1 and 2) can be ascribed to the residual sand deposits [31]. The $\sum$ REE values are low in the coastal area off Leizhou Peninsula and the eastern exit of Qiongzhou Strait, where the seismic sub-bottom profiles are dominated by sand waves [17]. These sandy deposits 
resulted from sediment eroded from the old stratum in the sea floor [32], implying a high-energy depositional environment. The low $\sum$ REE value area off the eastern Hainan Island is associated with the coarse-grained terrigenous sediments from the Wanquan River.
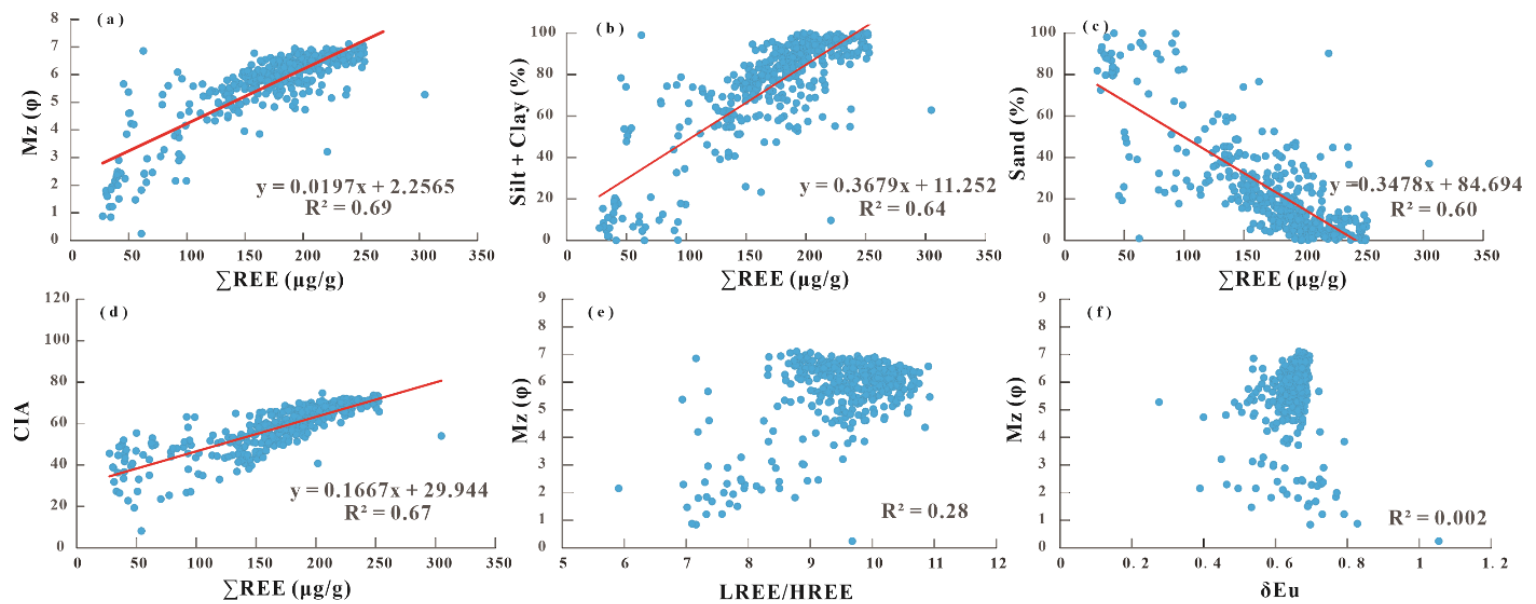

Figure 5. Correlations between total concentrations of REEs ( $\sum$ REE) with (a) Mz, (b) silt + clay, (c) sand and (d) chemical index of alteration (CIA), and Mz with (e) light REEs (LREE)/heavy REEs (HREE), and (f) $\delta \mathrm{Eu}$. The granulometric data and CIA are cited from Ge et al. [18].

As unstable minerals have been removed by acid digestion, the REEs reported in this study are dominated by the weathering processes of siliciclastic minerals [29]. Chemical weathering affects the residual fractions of the REEs compositions, and such an effect is most salient in LREE, which has high contents of essential weathering minerals [33]. The chemical index of alteration (CIA) can be utilized to quantify the weathering states of riverine sediments [34]. The plot of $\sum$ REE and CIA [18] indicates a strong positive correlation, with a correlative coefficient $\left(R^{2}\right)$ of 0.67 (Figure 5$)$. Such correlation suggests that the different weathering mechanisms exert an important influence on the $\sum R E E$ values. The climate in the sediment provenance area has been warm and humid. Chemical weathering promotes the REEs mobilization and fractionation. While LREE is preferentially adsorbed onto suspended particles [35], HREE is preferentially migrated away in forms of bicarbonate and organic complex in solutions [36]. Compared with LREE, HREE is more mobile for weathering products from granite.

Despite a relatively low abundance in sediments, heavy minerals could considerably contribute to the fraction of bulk REEs [2]. As shown in Table 2, the mean content of heavy minerals in zone II $(2.76 \%)$ is the highest among the three zones [28]. Nevertheless, the parameters for REEs fractionation, including $\delta \mathrm{Ce}, \delta \mathrm{Eu}, \mathrm{LREE} / \mathrm{HREE},(\mathrm{La} / \mathrm{Sm})_{\mathrm{N}}$, and $(\mathrm{Gd} / \mathrm{Lu})_{\mathrm{N}}$, do not exhibit similar variations with those of the heavy minerals. As heavy minerals contribute less than $20 \%$ of the $\sum R E E$ in riverine sediments [6], the heavy minerals will not be the dominant factor on $\sum$ REE. In general, diagenesis will change the $\mathrm{Ce}$ anomalies and make $\delta \mathrm{Ce}$ have strong correlations with both $\sum \mathrm{REE}$ and $\delta \mathrm{Eu}$ [37]. However, the $\sum$ REE and $\delta$ Eu show weak relationships with $\delta$ Ce in this study area, yielding an $R^{2}$ of 0.17 and 0.01, respectively (Figure 6), which implies that diagenesis is not a dominant factor for the $\sum$ REE. 

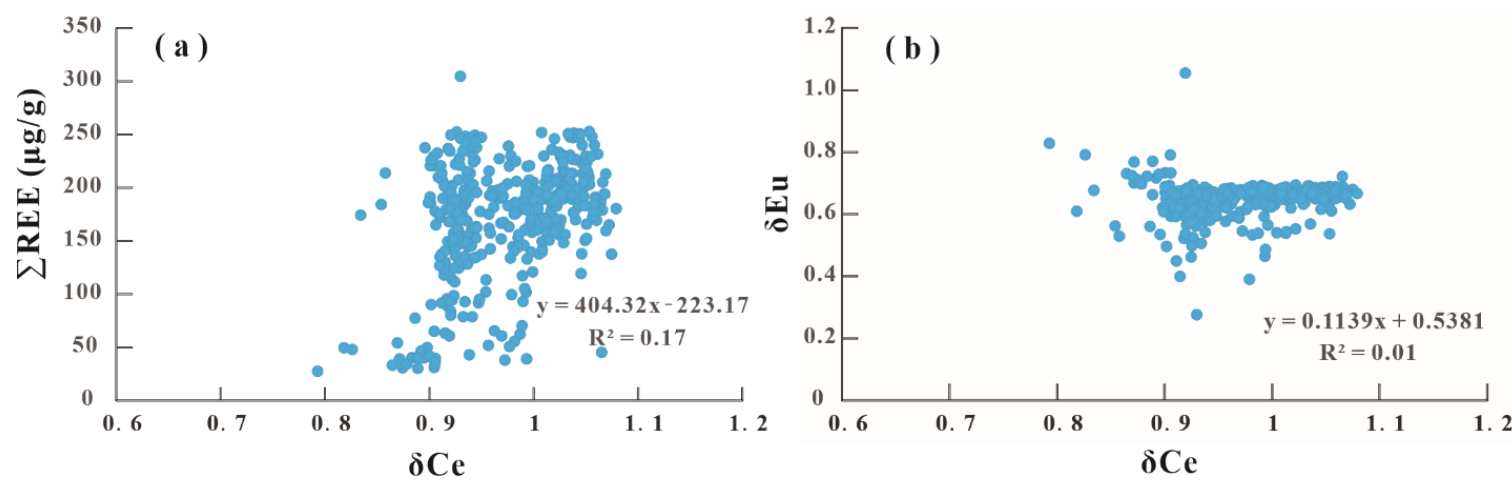

Figure 6. Correlations between cerium anomalies ( $\delta \mathrm{Ce})$ with $(\mathbf{a}) \sum \mathrm{REE}$ and $(\mathbf{b})$ europium anomalies $(\delta \mathrm{Eu})$.

\subsection{Provenance and Transport Route of the Sediments}

In general, terrigenous materials transported by rivers are the dominant sediment source in shallow waters [27]. Due to the REEs' conservative behavior in hypergene environments, REEs characteristics can be used to trace the origins of fluvial sediments. Geologically, the South China continent mostly consists of magmatic rocks (mainly granite) and metamorphic rocks [21,38]. If the source rock is granite, the $\sum$ REE value is relatively high and LREE is relatively rich, while the Eu represents an obvious negative anomaly [39]. The average $\sum$ REE value $(192.94 \mu \mathrm{g} / \mathrm{g})$ reported in this study is consistent with the shelf sediments along the Western Pacific $(156.00 \mu \mathrm{g} / \mathrm{g}$, [30]). The REEs abundance of the sediments in this study are also roughly close to the Chinese Loess (171.00 $\mu \mathrm{g} / \mathrm{g}$; [30]), the Taiwanese rivers

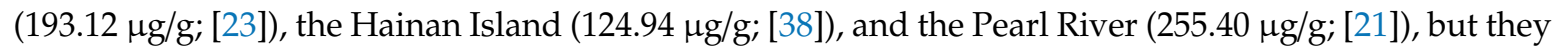
are quite different from deep sea clay $(411 \mu \mathrm{g} / \mathrm{g}$; [40]). Chondrite-normalized REEs of sediments are characterized by relatively high LREE and a negative Eu anomaly (Figure 3). The REEs fractionation patterns of sediments in the study area are comparable of those of terrigenous materials, such as the sediments from the Pearl River [21], Hainan Island [24], southwestern Taiwanese rivers [23], Qiongzhou Strait [22], and SCS slope [25]. We also use the discrimination function (DF) to analyze the proximity of the northern SCS sediments to these potential provenances.

$$
\mathrm{DF}=\left|\left(\mathrm{C}_{1 \mathrm{~S}} / \mathrm{C}_{2 \mathrm{~S}}\right) /\left(\mathrm{C}_{1 \mathrm{P}} / \mathrm{C}_{2 \mathrm{P}}\right)-1\right|
$$

where $C_{1 S} / C_{2 S}$ and $C_{1 P} / C_{2 P}$ represent the ratio of two elements, with similar chemical properties in the sediments from the study area and potential provenance. In this study, we choose $\mathrm{Sm} / \mathrm{Nd}$ to calculate DF [37]. It is generally considered that the chemical properties of the sediments from the study area are close to those of the potential provenance if the value of DF is less than 0.5 . All DF values between the study area and Pearl River, Hainan Island, southwestern Taiwanese rivers, Qiongzhou Strait, and SCS slope sediments are very low (Table 3). Both REEs fractionation patterns and DF values (Figure 3, Table 3) show that the REEs have strong terrigenous succession and the surface sediments in the northern SCS shelf are mainly from the surrounding continents.

Table 3. Discrimination function (DF) values of the sediments.

\begin{tabular}{ccc}
\hline Potential Provenance & DF & Reference \\
\hline Pearl River & 0.02 & {$[21]$} \\
Hainan Island & 0.05 & {$[24]$} \\
Southwestern Taiwanese rivers & 0.07 & {$[23]$} \\
Qiongzhou Strait & 0.03 & {$[22]$} \\
SCS slope & 0.03 & {$[25]$} \\
\hline
\end{tabular}

As a result of their weak correlations with grain size, fractionation parameters, such as LREE/HREE ratio and $\delta \mathrm{Eu}$, are ideal proxies to trace the sources of the fluvial sediments (Figure 5). The LREE/HREE 
ratio in the study area ranges from 5.91 to 10.93 with an average value of 9.50 , which is comparable with those reported for the Pearl River (7.83-11.23; average: 8.98, [21]), Taiwanese rivers (7.48-13.03; average: 8.88, [23]), and Hainan Island (5.16-12.33, average: 9.52, [38]). The diagram of LREE and HREE exhibits a similar positive correlation in all sediment groups (Figure 7). In detail, the Pearl River samples show the highest $\sum$ REE on average, and the Hainan Island sediments have the lowest. The $\sum$ REE values of the study area and Taiwanese riverine samples fall in the middle. Most of the sediments from zone I have relatively uniform and higher LREE and HREE concentrations, indicating a source from the Pearl and Taiwanese rivers. The LREE vs. HREE values in zone II show scattered REEs fractionation, indicating a unique terrigenous source (Figure 7). The distribution patterns indicate enhanced influences from the Hainan Island and Qiongzhou Strait. Sediments in zone III exhibit the highest mean value of LREE/HREE ratio in the study area (Table 2), reflecting the highest fractionation degree. The plots of LREE vs. HREE in zone III shift to the ranges of sediments from the Hainan Island and SCS slope (Figure 7), which indicates the increased influences from these areas.

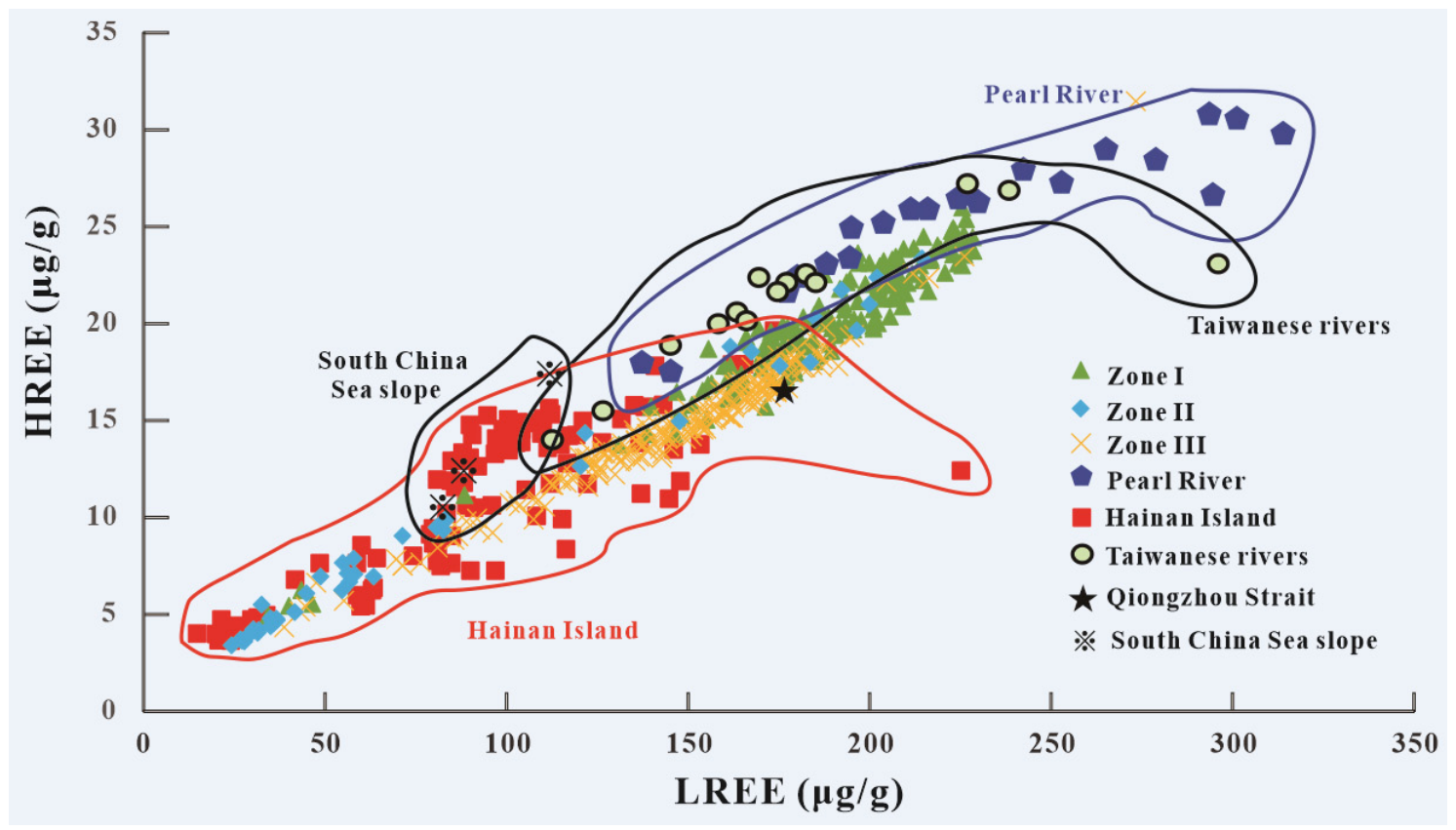

Figure 7. Correlations between LREE and HREE in the study area and potential provenances (the Pearl River data are cited from [21]; the Hainan Island data are cited from [24]; the Taiwanese rivers data are cited from [23]; the Qiongzhou Strait data are cited from [22]; the South China Sea slope data are cited from [25]).

Here, we summarize the modern transportation and depositional processes of sediments on the northern SCS continental shelf (Figure 8) based on the characteristics of the REEs from this study and the grain size, geochemical characteristics [18], sub-bottom profiles [17], and hydrodynamic conditions from previous studies. Under the impact of the East Asian summer monsoon, the weathering and erosion rates in the South Chinese Mainland and Taiwan are high; thus, huge amounts of riverine from the South Chinese Mainland rivers (Pearl River and surrounding small rivers, such as Moyang River, Jian River and so on) and southwestern Taiwanese rivers could flow into the ocean and deposit near the estuary. The strong East Asian winter monsoon strengthens the Chinese Coastal Current, which controls the southwestward longshore transport of re-suspended sediments. During this process, coarse fractions of re-suspended sediments could be transported over a relative short distance and then be deposited firstly, while fine particles could be dispersed over $400 \mathrm{~km}$ to the east of Leizhou Peninsula. The coastal current meets with the irregular diurnal tide to form a cyclonic circulation in this area [41,42]. The seawater's carrying capacity is reduced sharply and results in the rapid deposition on the distal depocenter (Figure 8). The sediments distributed in the east end of Qiongzhou Strait have the coarsest grain size and lowest $\sum$ REE in the study area. The coarse materials are mainly 
re-suspended and transported from the Qiongzhou Strait. With transport southward, the influence of the Hainan Island-derived sediments (such as Wanquan River, Nandu River sediments, and so on) increases. Meanwhile, the sediments from SCS slope could be delivered into the relatively deep-water region during summer.

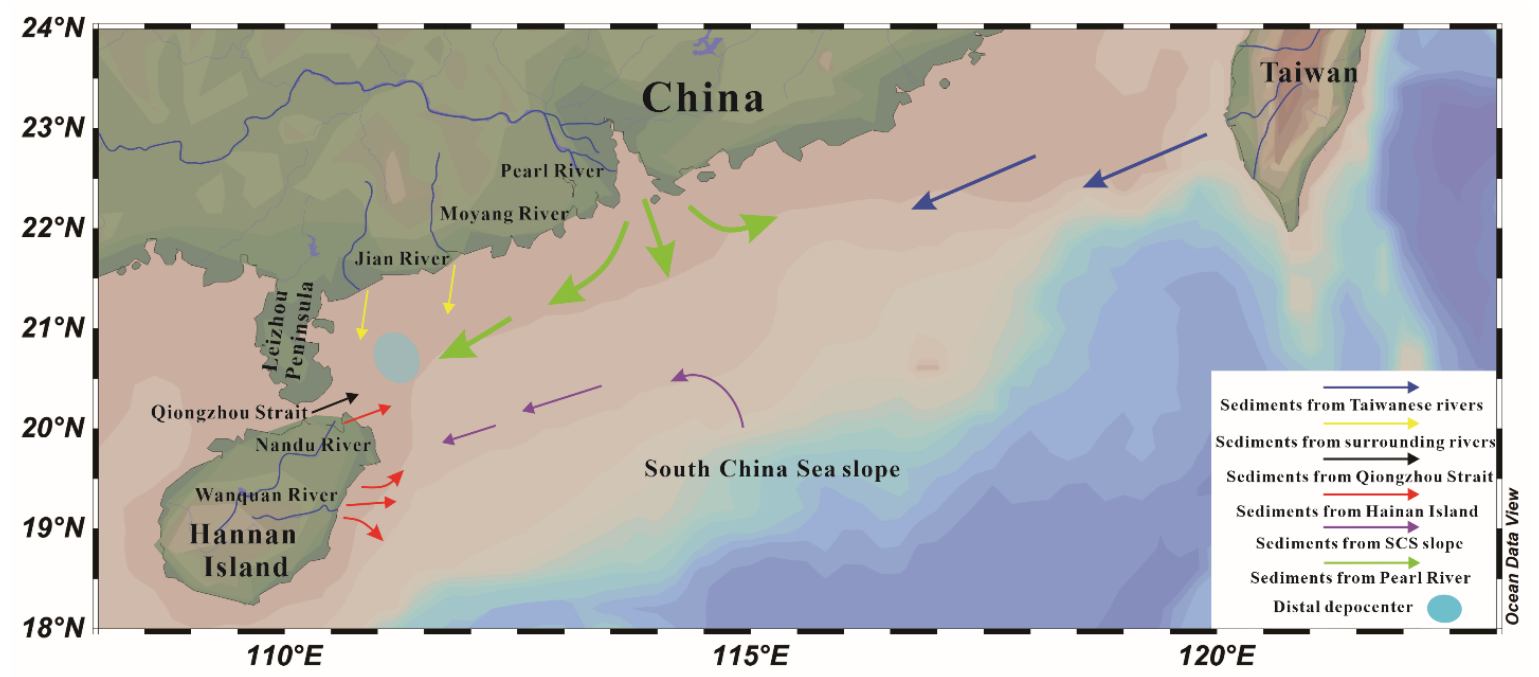

Figure 8. Transport patterns of modern sediments on the northern South China Sea continental shelf.

\section{Conclusions}

REEs analysis was performed on 388 surface sediments in the northern SCS. The $\sum$ REE values range from 32.97 to $349.07 \mu \mathrm{g} / \mathrm{g}$, with an average value of $192.94 \mu \mathrm{g} / \mathrm{g}$. The REEs are dominated by LREE, with a mean value of $154.36 \mu \mathrm{g} / \mathrm{g}$; the mean value of HREE is $16.11 \mu \mathrm{g} / \mathrm{g}$. The $\sum$ REE values are high in the western Guangdong coastal waters. Two accumulation centers are identified near the Xiachuan and Hailing Islands, and the lowest value is located in the eastern Leizhou Peninsula and Qiongzhou Strait. The fractionation parameters reflect a remarkable LREE accumulation, relatively flat HREE patterns, and negative Eu anomalies. The REEs compositions are mainly controlled by source rock properties, hydrodynamic conditions, and intensity of chemical weathering. The study area was divided into three zones according the results of Q-cluster analysis. Zone I is around on the continental shelf off the Guangdong Province, with a mean $\sum R E E$ value of $233.96 \mu \mathrm{g} / \mathrm{g}$. The sediments from zone I have relatively uniform and higher LREE and HREE concentrations, indicating sources from the Pearl River and Taiwanese rivers. Zone II is located in the coastal area off Leizhou Peninsula and eastern end of the Qiongzhou Strait, and it has an averaged $\sum$ REE value of $107.00 \mu \mathrm{g} / \mathrm{g}$. The distribution patterns of REEs indicate elevated influences from the Hainan Island and Qiongzhou Strait. Zone III covers the outer shelf waters and eastern Hainan Island. The mean $\sum R E E$ value in this zone is $180.81 \mu \mathrm{g} / \mathrm{g}$. The plots of LREE and HREE show that the Hainan Island and SCS slope sediments dominate in this zone. Based on the compositions of REEs, grain size, geochemical characteristics, sub-bottom profiles, and hydrodynamic conditions in the study area, a modern sediment dispersal route can be reconstructed.

Author Contributions: Conceptualization, Q.G., Z.G.X. and F.C.; methodology, Q.G.; software, Q.G.; validation, Q.G., Z.G.X. and F.C.; writing-original draft preparation, Q.G.; writing-review and editing, Z.G.X. and F.C.; project administration, Q.G. and F.C.; funding acquisition, Q.G. and F.C. All authors have read and agreed to the published version of the manuscript.

Funding: This research was funded by the National Programme on Global Change and Air-Sea Interaction (Grant No. GASI-GEOGE-03), and the National Natural Science Foundation of China (Grant Nos. 41476047 and 41106045).

Conflicts of Interest: The authors declare no conflict of interest. 


\section{References}

1. Singh, P.; Rajamani, V. REE geochemistry of recent clastic sediments from the Kaveri floodplains, southern India: Implication to source area weathering and sedimentary processes. Geochim. Cosmochim. Acta 2001, 65, 3093-3108. [CrossRef]

2. Taylor, S.R.; McLennan, S.M. The Continental Crust: Its Composition and Evolution; Blackwell: Oxford, UK, 1985; pp. 1-190.

3. Gu, S.; Chen, S.; Wu, B.; Li, S.; Chen, Y. REE geochemistry in surface sediments of South China Sea. Trop. Oceanol. 1989, 8, 93-101. (In Chinese with English Abstract)

4. Mazumdar, A.; Banerjee, D.; Schidlowski, M.; Balaram, V. Rare-earth elements and Stable Isotope Geochemistry of early Cambrian chert-phosphorite assemblages from the Lower Tal Formation of the Krol Belt (Lesser Himalaya, India). Chem. Geol. 1999, 156, 275-297. [CrossRef]

5. Munksgaard, N.C.; Lim, K.; Parry, D.L. Rare earth elements as provenance indicators in North Australian estuarine and coastal marine sediments. Estuar. Coast. Shelf Sci. 2003, 57, 399-409. [CrossRef]

6. Yang, S.; Jung, H.S.; Choi, M.S.; Li, C.X. The rare earth element compositions of the Changjiang (Yangtze) and Huanghe (Yellow) river sediments. Earth Planet. Sci. Lett. 2002, 201, 407-419. [CrossRef]

7. Li, M.; Ouyang, T.; Zhu, Z.; Tian, C.; Peng, S.; Tang, Z.; Qiu, Y.; Zhong, H.; Peng, X. Rare earth element fractionations of the northwestern South China Sea sediments, and their implications for East Asian monsoon reconstruction during the last 36 kyr. Quat. Int. 2019, 525, 16-24. [CrossRef]

8. Liu, J.; Chen, Z.; Yan, W.; Chen, M.; Yin, X. Geochemical characteristics of rare earth elements in the fine-grained fraction of surface sediment from South China Sea. Earth Sci. J. China Univ. Geosci. 2010, 35, 563-571. (In Chinese with English Abstract)

9. Wu, M. REE geochemistry of sea-floor sediments from the Taiwan shallow, China. Geochimica 1983, 3, 303-313. (In Chinese with English Abstract)

10. Jintu, W. REE geochemistry of surficial sediments from the Yellow Sea of China. Chin. J. Geochem. 1991, 10, 88-98. [CrossRef]

11. Zhao, Y.; Yan, M. Geochemistry of Sediments of the China Shelf Sea; Science Press: Beijing, China, 1994; pp. 5-130. (In Chinese)

12. Wang, L.; Sarnthein, M.; Erlenkeuser, H.; Grimalt, J.O.; Grootes, P.M.; Heilig, S.; Ivanova, E.A.; Kienast, M.; Pelejero, C.; Pflaumann, U. East Asian monsoon climate during the Late Pleistocene: High-resolution sediment records from the South China Sea. Mar. Geol. 1999, 156, 245-284. [CrossRef]

13. Jian, Z.; Zhao, Q.; Cheng, X.; Wang, J.; Wang, P.; Su, X. Pliocene-Pleistocene stable isotope and paleoceanographic changes in the northern South China Sea. Palaeogeogr. Palaeoclim. Palaeoecol. 2003, 193, 425-442. [CrossRef]

14. Wang, P.; Li, Q.; Tian, J.; He, J.; Jian, Z.; Ma, W.; Dang, H. Monsoon influence on planktic $\delta 18 \mathrm{O}$ records from the South China Sea. Quat. Sci. Rev. 2016, 142, 26-39. [CrossRef]

15. Gai, C.; Liu, Q.; Roberts, A.P.; Chou, Y.; Zhao, X.; Jiang, Z.; Liu, J. East Asian monsoon evolution since the late Miocene from the South China Sea. Earth Planet. Sci. Lett. 2020, 530, 115960. [CrossRef]

16. Liu, Z.; Colin, C.; Li, X.; Zhao, Y.; Tuo, S.; Chen, Z.; Siringan, F.P.; Liu, J.T.; Huang, C.-Y.; You, C.-F.; et al. Clay mineral distribution in surface sediments of the northeastern South China Sea and surrounding fluvial drainage basins: Source and transport. Mar. Geol. 2010, 277, 48-60. [CrossRef]

17. Ge, Q.; Liu, J.P.; Xue, Z.; Chu, F. Dispersal of the Zhujiang River (Pearl River) derived sediment in the Holocene. Acta Oceanol. Sin. 2014, 33, 1-9. [CrossRef]

18. Ge, Q.; Xue, Z.G.; Ye, L.; Xu, D.; Yao, Z.; Chu, F. Distribution Patterns of Major and Trace Elements and Provenance of Surface Sediments on the Continental Shelf off Western Guangdong Province and Northeastern Hainan Island. J. Ocean Univ. China 2019, 18, 849-858. [CrossRef]

19. Sun, S.-S.; McDonough, W.F. Chemical and isotopic systematics of oceanic basalts: Implications for mantle composition and processes. Geol. Soc. Lond. Spéc. Publ. 1989, 42, 313-345. [CrossRef] 
20. Boynton, W.V. Geochemistry of the Rare Earth Elements: Meteorite Studies. In Rare Earth Element Geochemistry; Henderson, P., Ed.; Elsevier: Amsterdam, The Netherlands, 1984; pp. 63-114.

21. Xu, Z; Han, G. Rare earth elements (REE) of dissolved and suspended loads in the Xijiang River, South China. Appl. Geochem. 2009, 24, 1803-1816. [CrossRef]

22. Cui, Z.A.; Hou, Y.M.; Xia, Z.; Lin, J.Q.; Liu, W.T.; Zhang, L. Geochemical characteristics and provenance analysis of Holocene sediments in Beibu Gulf, South China Sea. Glob. Geol. 2015, 34, 605-614. (In Chinese with English Abstract)

23. Li, C.-S.; Shi, X.-F.; Kao, S.-J.; Liu, Y.-G.; Lyu, H.-H.; Zou, J.-J.; Liu, S.-F.; Qiao, S.-Q. Rare earth elements in fine-grained sediments of major rivers from the high-standing island of Taiwan. J. Asian Earth Sci. 2013, 69, 39-47. [CrossRef]

24. Sheng, Y. Geochemical Characteristics of Rare Earth Elements in Soils of Nandu River Basin; Qingdao University: Qingdao, China, 2011; pp. 16-27. (In Chinese with English Abstract)

25. Zhao, Q.; Gong, J.; Li, S.; He, X.; Fu, S. Geochemical characteristics of rare earth elements of surface sediments in shenhu area of South China Sea. Mar. Geol. Quat. Geol. 2010, 30, 65-70. [CrossRef]

26. Shi, X.; Liu, S.; Fang, X.; Qiao, S.; Khokiattiwong, S.; Kornkanitnan, N. Distribution of clay minerals in surface sediments of the western Gulf of Thailand: Sources and transport patterns. J. Asian Earth Sci. 2015, 105, 390-398. [CrossRef]

27. Liu, S.; Zhang, H.; Zhu, A.; Wang, K.; Chen, M.; Khokiattiwong, S.; Kornkanitnan, N.; Shi, X. Distribution of rare earth elements in surface sediments of the western Gulf of Thailand: Constraints from sedimentology and minerlogy. Quat. Int. 2019, 527, 52-63. [CrossRef]

28. Chu, F. Report of the Marine Sediment's Characteristics in Zone CJ17; Second Institute of Oceanography, Ministry of Natural Resources: Hangzhou, China, 2010; pp. 48-57. (In Chinese)

29. Dou, Y.; Yang, S.; Liu, Z.; Clift, P.D.; Shi, X.; Yu, H.; Berne, S. Provenance discrimination of siliciclastic sediments in the middle Okinawa Trough since 30ka: Constraints from rare earth element compositions. Mar. Geol. 2010, 275, 212-220. [CrossRef]

30. Zhao, Y.; Wang, J.; Qin, C.; Chen, Y.; Wang, X.; Wu, M. Rare-earth elements in continental shelf sediments of the China Sea. Acta Sedimentol. Sin. 1990, 8, 37-43. (In Chinese with English Abstract)

31. Luo, Y.; Feng, W.; Lin, H. Bottom sediment types and depositional characteristics of sediments of the South China Sea. Trop. Oceanol. 1994, 13, 47-54. (In Chinese with English Abstract)

32. Wang, W. Propagation of tidal waves and development of sea-bottom sand ridges and sand ripples in northern South China Sea. Tropic Oceanol. 2000, 19, 1-7. (In Chinese with English Abstract)

33. Elderfield, H.; Upstill-Goddard, R.; Sholkovitz, E. The rare earth elements in rivers, estuaries, and coastal seas and their significance to the composition of ocean waters. Geochim. Cosmochim. Acta 1990, 54, 971-991. [CrossRef]

34. Liu, Z.; Colin, C.; Huang, W.; Le, K.P.; Tong, S.; Chen, Z.; Trentesaux, A. Climatic and tectonic controls on weathering in south China and Indochina Peninsula: Clay mineralogical and geochemical investigations from the Pearl, Red, and Mekong drainage basins. Geochem. Geophys. Geosyst. 2007, 8. [CrossRef]

35. Byrne, R.H.; Kim, K.-H. Rare earth element scavenging in seawater. Geochim. Cosmochim. Acta 1990, 54, 2645-2656. [CrossRef]

36. Song, Y.H.; Shen, L.P.; Wang, X.J. Preliminary discussion on REE in weathering crusts of selected rock types. Chin. Sci. Bull. 1987, 32, 695-698.

37. Yan, B.; Miao, L.; Huang, W.; Chen, Z.; Lu, J.; Gu, S.; Yan, W. Characteristics of rare earth elements in the surface sediments from the bays along the coast of Guangdong Province and their source tracers. J. Trop. Oceanogr. 2012, 31, 67-79. (In Chinese with English Abstract)

38. Ma, R.; Yang, Y.; He, Y. Geochemistry of rare earth elements in coastal and estuarial areas of Hainan's Nandu River. J. Chin. Rare Earth Soc. 2010, 28, 110-114. (In Chinese with English Abstract)

39. Cullers, R.L. The geochemistry of shales, siltstones and sandstones of Pennsylvanian-Permian age, Colorado, USA: Implications for provenance and metamorphic studies. Lithos 2000, 51, 181-203. [CrossRef]

40. Shen, H. Rare earth elements in deep-sea sediments. Geochimica 1990, 19, 340-348. (In Chinese with English Abstract) 
41. Li, Z.; Ke, X. Preliminary study on tidally-induced sediment fluxes of the Qiongzhou strait. Mar. Sci. Bull. 2000, 19, 42-49. (In Chinese with English Abstract)

42. Li, K.; Yin, J.; Huang, L.; Zhang, J.; Lian, S.; Liu, C. Distribution and abundance of thaliaceans in the northwest continental shelf of South China Sea, with response to environmental factors driven by monsoon. Cont. Shelf Res. 2011, 31, 979-989. [CrossRef]

Publisher's Note: MDPI stays neutral with regard to jurisdictional claims in published maps and institutional affiliations.

(C) 2020 by the authors. Licensee MDPI, Basel, Switzerland. This article is an open access article distributed under the terms and conditions of the Creative Commons Attribution (CC BY) license (http://creativecommons.org/licenses/by/4.0/). 